\title{
H3C4 Gene
}

National Cancer Institute

\section{Source}

National Cancer Institute. H3C4 Gene. NCI Thesaurus. Code C154500.

This gene plays a role in chromosome dynamics. 